\title{
S5ynthesis
}

International Scientific Conference of IT and Business-Related Research

\section{THE IMPACT OF DEMOGRAPHIC FACTORS ON NEGOTIATION ETHICS}

\author{
UTICAJ DEMOGRAFSKIH FAKTORA NA PREGOVARAČKU ETIKU
}

\author{
Gordana Dobrijević, Jelena Đorđević Boljanović, Vladimir Džamić \\ Singidunum University, Danijelova 32, Belgrade, Serbia
}

\begin{abstract}
:
Demographic factors have a great impact on people's ethical behaviour. This paper shall place special emphasis on national culture, gender and age. There are no universal ethical norms, and every culture has different standards of business ethics. Gender differences in negotiation behaviour come from different roles that women and men have in any given society, and different expectations they have from negotiations. There are also significant differences between older and younger participants in various types of research on ethical decision-making. There are some other factors with substantial influence on one's ethical behaviour, such as personality traits and situational factors, but they shall not be analyzed in this paper.
\end{abstract}

\section{Key words:}

negotiation ethics, demographic factors, national culture, gender, age.

\section{INTRODUCTION: NEGOTIATION ETHICS}

We define ethics as the principles, values, and beliefs that define right and wrong decisions and behaviour (Robbins \& Coulter, 2012), or as widely practiced social standards for what is right or wrong in a particular situation (Lewicki et al., 2010).

Ethics in negotiation is mostly concerned with standards of truth telling - how honest and disclosing a negotiator should be. While some negotiation tactics are clearly unethical (deception and lying), there are also many ethically ambiguous tactics in negotiations (e.g. emotional manipulation, misrepresentation, or bluffing). Some lesser forms of untruth, e.g. misrepresentation of one's true position, bluffing, and emotional manipulation, are ethically acceptable by some negotiators. On the contrary, absolute deception and falsification are normally regarded as unacceptable. Also, far more people are willing to lie by omission (not revealing the whole truth) than by commission (lying) (Lewicki et al., 2010).

The fundamental ethics of negotiation is finding the resolution or an outcome that all parties consider favourable (van Es, 1996, as cited in Murithi, 2009). According to Cooks and Hale (1994, as cited in Murithi, 2009), the main barrier to successful negotiation is "...instrumentalisation of a process to suit the self-interests of one particular party at the expense of the other parties." Behaviour of one party definitely affects the behaviour of the other party/parties, and unethical behaviour tend to lead to decreased trust or distrust (De Cremer et al., 2010). The unfair behaviour, in general, is perceived as unethical when people violate the rules and values the society applies in order to coordinate and collaborate (Tenbrunsel \& Smith-Crowe, 2008).

\section{Apstrakt:}

Demografski faktori u velikoj meri utiču na etičko ponašanje pojedinca. Ovaj rad stavlja naglasak na nacionalnu kulturu, pol i starost. $\mathrm{Na}$ postoje univerzalne etičke norme, i u svakoj kulturi postoje različiti standardi vezani za poslovnu etiku. Rodne razlike u pregovaračkom ponašanju proističu iz različitih uloga koje žene i muškarci imaju u društvu, kao i razlika u očekivanjima od samog procesa pregovaranja. Primetne su značajne razlike između starijih i mlađih učesnika u različitim istraživanjima o etičkom odlučivanju. Postoje još neki faktori koji u velikoj meri utiču na etičko ponašanje pojedinca, poput osobina ličnosti i situacionih faktora, ali oni nisu obuhvaćeni ovim radom.

\section{Ključne reči:}

pregovaračka etika, demografski faktori, nacionalna kultura, pol, starost.

We also have to bear in mind that, at least according to the behavioural model, some unethical acts are performed unconsciously (De Cramer et al., 2011). These authors make a distinction between ethicality and intentionality - it means that sometimes people do bad things without knowing what they are doing. Despite the awareness of business people about what is right and wrong, unethical behaviours still emerge. Some situations are more compelling for nearly anyone to undertake unethical behaviour.

Negotiation is one of those situations. Some people think there is no ethics in negotiations, and that negotiators should just do whatever is necessary to achieve their goals. However, even they disclose more information than legally required when dealing with family and friends (Dobrijević, 2011). Others think that negotiators should say "truth and nothing but the truth". The majority of negotiators are somewhere between these two opinions, trying to be as honest as possible, but still not revealing the vital information. This requires negotiators to walk a thin line: if they stay on the right side of the line, they will get the trust and cooperation of the other side. If they cross the line, their reputation will be ruined (Lewicki, 2007).

Some social forces can stimulate negotiators to set aside their own ethical standards and perform acts that are ethically questionable (Lewicki et al., 2010): acting as an agent to others and being under their pressure to achieve; viewing negotiation as a game, and therefore assuming that the rules of the game should be applied; being a member of a group that tolerates breaking the rules in order to achieve success; being so loyal to your group so that you would do anything to be rewarded for your loyalty; and following the orders of your superiors who tell you to get the job done, no matter what it takes. 


\section{DEMOGRAPHIC FACTORS}

Apart from personality differences (e.g. competitiveness and locus of control) and situational factors, the strongest predictors of ethical behaviour are demographical factors. In this paper, we shall focus on national culture, gender and age, although religious orientation, education and work experience are also among these factors.

\subsection{NATIONAL CULTURE}

There are no universal ethical norms. Standards of business ethics are quite different in different cultures. The question is, whose standards should be respected when negotiating with people from other cultures? As Michaelson (2010) found out, Western scholars and business people think that standards of their home countries are higher and more restrictive than in some less developed countries across the Globe. They don't generally imply that the people of those countries behave less ethically than the people from the Western countries, only that their political and legal systems don't allow for fair and free market capitalism. This author thinks that the justification for many ethical norms in Western countries may come more as a result of their economic power, and not of their moral authority. That means that economic expansion of the Western countries seems to be taken as evidence that their form of free market capitalism should be a global standard that all other countries should strive to accomplish.

The things that are unacceptable in the West are quite normal in the Far East. For instance, "Entering through the back door" or through business connections is a common practice in China, South Africa or Nigeria. You can't really do any business in China without these informal connections, or guanxi. International contracts are another problem. In the West, a contract is a document that must be followed to the letter, while for the Korean, Chinese and Japanese, contracts are only a starting point in building mutual relationships and trust. How can we interpret taking a potential business partner on a cruise? Is it a bribe or just working on a good relationship with your partner? Obviously, the cruise can affect making an important decision. Would it be any different if it were just an expensive dinner? In the countries of Latin America, it is a common practice to "seal the deal" with a present, while giving presents in the USA would be an illegal act.

Husted (1999) and Volkema (2001) found a connection between Hofstede's cultural dimensions (Hofstede, 1997) and ethical behaviour. Negotiators coming from cultures with high individualism, high masculinity and low uncertainty avoidance might be more likely to see those tactics as adequate and acceptable than individuals whose cultures have opposite attributes (Volkema, 2001).

\subsection{GENDER AND AGE}

Literature shows conflicting opinions on the impact of gender on ethical decision-making. Many studies, e.g. Kelly, Ferrell and Skinner (1990), Smith and Oakley (1997), Dawson (1997), Deshpande (1997), Peterson, Rhoads, and Vaught (2001) and Albaum (2006) ascribe differences in ethicality to gender and claim that women have higher ethical standards. The research of Kelly, Ferrell and Skinner (1990) showed that female and older participants had higher ethical standards. The same holds true for the participants working on the present job for at least ten years. Deshpande (1997) and Borkowski and Ugras (1998) also found that women had higher ethical standards than men, while older respondents had higher standards than the younger ones. Dawson (1997) compared sales professionals in two age groups. Salespeople in their twenties had lower ethical standards than the salespeople in their forties and fifties. She found that that ethical standards increase along with the age and experience in the sales profession. She also came to an interesting correlation between age and sex. Namely, women in all age groups demonstrated higher ethical standards, but that difference decreased as the age increased. Volkema's (2001) study also showed that younger male negotiators may be more likely to use some dishonest negotiation tactics than older negotiators or women. Peterson, Rhoads, and Vaught (2001) had similar findings.

Sidani et al. (2009) found very small gender-based differences in ethicality (women being more sensitive, especially in younger groups), but quite significant difference based on age, with older participants having higher ethical norms. These authors also found decreased differences with increased maturity of participants.

On the other hand, there are the studies that did not find any effects of gender or age on individual ethical standards, e.g. Nikoomaram et al. (2013) and Gupta et al. (2010). Dobrijević (2014) also found that there are no gender-based differences in ethical decision-making in the negotiation setting. Lang (1993) discovered that negotiation behavior is more influenced by professional culture than national culture. In the Greek setting, Feidakis and Tsaoussi (2009) showed that gender did not have any influence on individual ethics. It was the professional norms (in this case participants were lawyers) that had a much greater influence on ethical decision-making.

According to Wyatt (1999), when women negotiate, they want to achieve a fair deal, while men negotiate to win. In Gender Socialization Theory, Volkema (2001) found an explanation for these gender differences. From an early age, boys are taught to obey rules and justice, while girls are instructed to pay attention to mutual relationships and compassion. One interpretation of age differences could be that young people are more pressured to achieve good results at work (Volkema, 2001). Another explanation is that as people grow older, they progress through stages of moral development (Kohlberg, 1984, as cited in Robbins \& Coulter, 2012). According to this theory, individual's morality develops throughout his/her lifespan.

\section{SUMMARY}

Ethical choices are influenced by national culture, gender and age, among other factors. By understanding the effects of different demographic determinants on ethical behaviour in negotiations and business in general, researchers and practitioners can better understand various types of (un)ethical behaviour. They can help in negotiation preparation and planning when negotiating with other cultures and/or with people from different demographic groups.

\section{REFERENCES}

Albaum, G. (2006). Ethical attitudes of future business leaders: Do they vary by gender and religiosity? Business Society, 45(3), 300-321. DOI: 10.1177/0007650306289388

Borkowski, S.C. \& Ugras, Y.J. (1998). Business students and ethics: A meta-analysis. Journal of Business Ethics, 17, 11171127. 
Dawson, L. (1997). Ethical differences between men and women in the sales profession. Journal of Business Ethics, 16, 11431152. DOI: $10.1023 / A: 1005721916646$

De Cramer, D., van Dick, R., Tenbrunsel, A., Pillutla, M., Murnighan, J.K. (2011). Understanding ethical behavior and decision making in management: A behavioural business ethics approach. British Journal of Management, 22, S1-S4.

Deshpande, S.P. (1997). Manager's perception of proper ethical conduct: The effect of sex, age and level of education. Journal of Business Ethics, 16, 79-85.

Dobrijević, G. (2011). Poslovno komuniciranje i pregovaranje (in Serbian). Belgrade: Singidunum University.

Dobrijević, G. (2014). The effect of gender on negotiation behaviour. Singidunum Journal of Applied Sciences, 11(1), 43-52. DOI: $10.5937 /$ sjas11-5973

Feidakis, A., Tsaoussi, A. (2009). Competitiveness, gender and ethics in legal negotiations: Some empirical evidence. International Negotiation, 14, 537-570.

Gupta, S., Swanson, N.J., \& Cunningham, D.J. (2010). A study of the effect of age, gender, \& gpa on the ethical behavior of accounting students. Retrieved from February 19, 2015 http://ssrn.com/abstract=1669467 or http://dx.doi. org/10.2139/ssrn.1669467

Hofstede, G. (1997). Cultures and Organizations: Software of the Mind. New York: McGraw-Hill.

Husted, B.W. (1999). Wealth, culture, and corruption. Journal of International Business Studies, 30: 339-360.

Kelly, S., Ferrell. O., \& Skinner, S. (1990). Ethical behavior among marketing researchers: An assessment of selected demographic characteristics. Journal of Business Ethics, 9(8), 681-88.

Lang, W. (1993). A professional's view. In Guy Olivier Faure and Jeffrey Z. Rubin, editors, Culture and Negotiation: The Resolution of Water Disputes. Newbury Park, CA: Sage Publications.

Lewicki, R., Barry, B. \& Saunders, D.M. (2010). Negotiation. Singapore: McGraw-Hill/Irwin.
Lewicki, R.J. (2007). Walk the line: Ethical dilemmas in negotiation, Negotiation, A Newsletter Published by the Program on Negotiation at Harvard Law School, 10(5). Retrieved February 19, 2015 from www.pon.harvard.edu/publications/newsletter/topic_index.php?topic $=9$

Michaelson, C. (2010). Revisiting the Global Business Ethics Question. Business Ethics Quarterly, 20(2), 237-251.

Murithi, T. (2009). The Ethics of Peacebuilding. Edinburgh: Edinburgh University Press

Nikoomaram, H., Roodposhti, F.R., Ashlagh, A.T., Lotfi, F.H., \& Taghipourian, Y. (2013). The Effects of age, gender, education level and work experience of accountant on ethical decision making by using fuzzy logic. International Research Journal of Applied and Basic Sciences, 4(6), 1559-1571.

Peterson, D., Rhoads, A., \& Vaught, B.C. (2001). Ethical beliefs of business professionals: A study of gender, age and external factors. Journal of Business Ethics, 31, 225-232.

Robbins, S., \& Coulter, M. (2012). Management. Harlow: Pearson Education Limited.

Sidani, Y., Zbib, I., Rawwas, M., \& Moussawer, T. (2009). Gender, age and ethical sensitivity: the case of Lebanese workers. Gender in Management: An International Journal, 24(3), 211-227. DOI: 10.1108/17542410910950886

Smith P.L., Oakley E.F. (1997). Gender related differences in ethical and social values of business students: implications for management. Journal of Business Ethics. 16(1), 37-45.

Tenbrunsel, A.E., \& Smith-Crowe, K. (2008). Ethical Decision-making: Where we've been and where we're going. Academy of Management Annals, 2, 545-607. DOI: 10.1080/19416520802211677

Volkema, R.J. (2001). Demographic, Cultural, and Economic Predictors of Perceived Ethicality of Negotiation Behavior: A Nine-Country Analysis. Academy of Management Proceedings, SIM A1-A6.

Wyatt, D. (1999). Negotiation strategies for men and women. Nursing Management, 30(1), 22-26. 